\title{
MTHFR C677T and TS 5'-UTR 3R/3R Gene Polymorphism in Methotrexate-Resistant Childhood Acute Lymphoblastic Leukemia
}

\author{
I Dewa Gede Ugrasena ${ }^{1, *}$, Harianto Notopuro ${ }^{2}$, Subijanto Marto Sudarmo ${ }^{1}$, \\ Ketut Sudiana ${ }^{3}$, Djajadiman Gatot ${ }^{4}$, Ponpon Idjradinata ${ }^{5}$ \\ ${ }^{1}$ Department of Child Health, Faculty of Medicine, Universitas Airlangga, Jl. Prof. Dr. Moestopo No. 6-8, Surabaya, Indonesia \\ ${ }^{2}$ Department of Biochemistry, Faculty of Medicine, Universitas Airlangga, Jl. Prof. Dr. Moestopo No. 6-8, Surabaya, Indonesia \\ ${ }^{3}$ Department of Patology Anatomy, Faculty of Medicine, Universitas Airlangga, Jl. Prof. Dr. Moestopo No. 6-8, Surabaya, Indonesia \\ ${ }^{4}$ Deparment of Child Health, Faculty of Medicine, Universitas Indonesia, Jl. Salemba Raya No. 6, Jakarta, Indonesia \\ ${ }^{5}$ Department of Child Health, Faculty of Medicine, Universitas Padjajaran, J1. Prof. Eyckman No. 38 Pasteur, Bandung, Indonesia \\ *Corresponding author. E-mail: ugrasena56@gmail.com
}

Received date: Dec 23, 2019; Revised date: Apr 23, 2020; Accepted date: May 5, 2020

\section{Abstract}

$\mathrm{B}$ ACKGROUND: Childhood acute lymphoblastic leukemia (ALL) is the most common pediatric malignancy in Indonesia and often treated by methotrexate (MTX). Though it can be cured in 30-60\% of patients, MTX resistance remains the major cause of treatment failure in childhood ALL. Previous sudies showed that its anti-leukemic property was moderated by MTX ability to inhibitmethylene tetra hydrofolate reductase (MTHFR) and thymidylate synthase (TS) in folate metabolism. This study investigates the correlation between MTHFR and TS polymorphism and MTX resistance in ALL children.

METHODS: A total of 155 subjects obtained from all subjects prior to chemotherapy. DNA from blood samples were extracted and underwent polymerase chain reaction- restriction fragment length polymorphism (PCR-RFLP) to evaluate MTHFR C677T and TS 5'-UTR 3R/3R polymorphism.

RESULTS: There was significant correlation between MTHFR C677T and TS 5'-UTR 3R/3R gene polymorphism with MTX resistance. Subjectswith MTHFR C677T and TS 5'-UTR 3R/3R gene polymorphism were 4 times $(p=0.007)$ and 6.4 times $(p=0.001)$ more likely to be MTX resistant than those without gene polymorphisms, respectively.

CONCLUSION: MTHFR C677T andTS 5'-UTR 3R/3R represent dominant gene polymorphism related to MTX resistance in childhood ALL.

KEYWORDS: gene polymorphism, folate metabolism, acute lymphoblastic leukemia

Indones Biomed J. 2020; 12(2): 177-82

\section{Introduction}

Acute lymphoblastic leukemia (ALL) is consider the most common malignancy in pediatric population, accounting for approximately $30 \%$ of all cancer in children, and current optimal use of anti-leukemic agents have pushed its cure rate above $85 \%$.(1) An important cytostatic drug used in the treatment of ALL is anti-folate methotrexate (MTX) which inhibits DNA synthesis. Folate are important component for synthesis of purine and pyrimidine, thus is essential for normal cell growth, DNA replication and repair. The polyglutamylated form of MTX acts as an inhibitor of enzyme thymidylate synthase (TS) and is and is an important enzymes, its gene is located in chromosome 18 and catalyses the conversion of deoxyuridylate monophosphate (dUMP) to deoxy thymidylate monophosphate (dTMP) thus TS is the key enzyme in de novo DNA synthesis. TS has unique tandem repeat sequence in the 5' untranslated region (UTR) immediately upstream of the ATG codon initiation start site that has been shown to be polymorphic, containing either two or three 28-bp repats. The second important enzymes 
in MTX is methylenetetrahydrofolate reductase (MTHFR) which catalyse the irreversible conversion of 5,10-MTHF into 5-MTHF in intracellular folate homeostasis. MTHFR gene is located in chromosome $1 \mathrm{p}$ and is subject to several polymorphisms. One of them a mutation $\mathrm{C}-\mathrm{T}$ at nucleotide position 677 which result in an alanine to valine substitution.

Around one-third of all patients experience treatment failure (2-5), probably caused by resistance to MTX, a chemotherapy used in ALL treatment (6). It is hypothesized that MTX resistance is caused by gene polymorphisms encoding various enzymes involved in folate metabolism, e.g., MTHFR and TS. In fact, these gene polymorphisms exist among different ethnic variations.(7-11) In Indonesia, the incidence of TS5'-UTR 3R/3R polymorphisms was $76.3 \%$ compared to $33.1 \%$ in Caucasian populations. (12) The incidence of MTHFR C677T polymorphisms in children without leukemia is also high in the Indonesian population.(13)

Meanwhile, MTHFR C677T and TS 5'-UTR 3R/3R gene polymorphismscould disrupt MTX activities by impeding the ability of MTX to suppress the enzymes responsible for lymphoblast DNA synthesis. Thus, DNA synthesis continues, resulting in MTX resistance. This study will investigate the correlation between MTHFR C677T and TS5'-UTR 3R/3R gene polymorphism and MTX resistance in childhood ALL.

\section{Methods}

\section{Subjects}

This study involved pediatric ALL patients, admitted to Dr. Soetomo General Hospital, Surabaya, from January 2013 to July 2016. Inclusion criteria werechildren aged 0-16 years old, ALL type L1 and L2 based on French-American-British (FAB) classification, no prior cytostatic chemotherapy treatment for leukemia, and regular participation in a chemotherapy treatment protocol. Subjects who met the inclusion criteria were included to the study and underwent treatmentaccording to National ALL Protocol 2006.(14) After 6 weeks, subjects were evaluated by bone marrow aspiration and classified as resistant if lymphoblast were more than 5\%. Ethical clearance was given by the Ethical Research Commission of Dr. Soetomo General Hospital, Surabaya, No. 50/Panke.KKE/2007.

\section{DNA Extraction}

Prior to the chemotherapy treatment, blood samples from study subjects were obtained and stored in a refrigerator using filter paper. Blood samples from the filter paper were diluted in $0.5 \mathrm{~mL}$ Tris-EDTA (TE) buffer (Cat. No. 93239, Sigma Aldrich, St. Louis, Missouri, USA). Mixture was centrifuged using SL 16 centrifuge (Thermo Fisher Scientific, Waltham, Massachusetts, USA) at 10,000-13,000 rpm. Pellet was suspended using vortex mixer (Fisher Scientific, Hampton, New Hampshire, USA) in $0.5 \mathrm{~mL}$ TE buffer. Samples were incubated using Thermo Scientific IMH100 Heratherm Advanced Protocol Microbiological Incubator (Thermo Fisher Scientific) in $56^{\circ} \mathrm{C}$ for 45 minutes, and again incubated in $95^{\circ} \mathrm{C}$ for 45 minutes.

\section{PCR Technique}

PCR was conducted using BioRad DNA Engine PTC-200 Peltier Thermal Cycler (Conquer Scientific, San Diego, California, USA). Primary sequence used for MTHFR C677T was 5'-CAG TCC CTG TGG TCT CTT CAT-3' (forward) and 5'-AGG ACG GTG CGG TGA GAG TG-3' (reverse), while for TS 5'-UTR 3R/3R 28 bp repeat was 5'-GTG GCT CCT GCG TTT CCC CC-3' (forward) and 5'-GGC TCC GAG CCG GCC ACA GGC ATG GCG CGG-3' (reverse) (synthesized by Eurogentec Biotechnology Company, Liege, Belgium). Mixture for MTHFR C677T contained Invitrogen Platinum Taq DNA Polymerase (Thermo Fisher Scientific), forward and reverse primer, and dNTP (Cat. No. R0181, Thermo Fisher Scientific). Mixture for TS 5' UTR 3R/3R 28 bp repeat contained HotStarTaqPlusDNA Polymerase (Cat. No. 203203, Qiagen, Hilden, Germany), forward and reverse primer, dNTP, and NeXtal Stock Dimethyl sulfoxide (Cat. No. 133037, Qiagen).

\section{RFLP Technique}

HinfI restriction enzyme (Catalog No. ER0801, Thermo Fisher Scientific) was used for MTHFR C677T and HaeIII restriction enzyme (Catalog No. ER0151, Thermo Fisher Scientific) was used for TS 5'-UTR 3R/3R $28 \mathrm{bp}$. Mixture was kept overnight before analysis. Gene, DNA fragment sizes after RFLP: MTHFR C677T wild type undigested 328 bp. Mutant digested $176 \mathrm{np}$ and $152 \mathrm{bp}$, while TS 5'-UTR 3R/3R 243 bp.

\section{DNA Analysis}

Gen polymorphism for TS 5'-UTR 3R/3R 28 bp was analyzed using ABI Prism 3100-Avant Genetic Analyzer (Applied Biosystems Biotechnology Company, Foster City, California, USA). Gen polymorphism for MTHFR C677T was analyzed using LightCycler 480 Instrument II (Roche Diagnostics, Basel, Switzerland). 


\section{Gel Electrophoresis}

PCR and RFLP products could be seen by $3 \%$ agarose gel electrophoresis and by adding ethidium bromide. Documentation was done using the Gel Doc system (BioRad Laboratories, Feldkirchen, Germany).

\section{Statistical Analysis}

Statistical analysis was conducted using IBM SPSS version 22 (IBM Corporation, Armonk, New York, USA). To see the relationship between MTX resistance and MTHFR C677T and TS5'-UTR 3R/3R gene polymorphisms, the chi-square test and Fisher's absolute test were performed. To study the effects of each type of gene polymorphism on MTX resistance, multiple logistic regression tests were used. To determine the effects of both single and combination polymorphisms on MTX chemotherapy resistance, logistic regression tests wereused.

\section{Results}

From a total of 167 samples involved in this study, only 155 subjects completed the study. Six subjects dropped out, 4 subjects refused the protocol therapy, and 2 other subjects were excluded due to incomplete medical records. PCR and RFLP results of MTHFR C677T and TS 5'-UTR 3R/3R polymorphisms can be seen in Figure 1 and Figure 2.

The average age was 5.67 years, the youngest subject was 8 months old and the oldest was 14 years old. Statistical tests on MTX resistance showed no correlation with age groups $(p>0.05)$ (Table 1). According to gender and lymphoblast cell morphology, there was no relationship between gender and cell morphology toward MTX resistance.

Table 2 showed that subjects with MTHFR C677T gene polymorphism were more likely to be resistant to MTX
(84.2\%) compared to those without gene polymorphism (60.7\%). Similar results were also seen on Table 3 in which subjects with TS 5'-UTR 3R/3R gene polymorphism were more likely to be resistant to MTX (71.3\%) compared to those without polymorphism (31.6\%). Multiple logistic regression tests showed that polymorphism of TS 5'-UTR 3R/3R and MTHFR C677T had significant correlation with MTX resistance. ALL subjects with TS 5'-UTR 3R/3R polymorphism had 6.4 times greater probability of being MTX resistant than patients without TS 5'-UTR 3R/3R polymorphism $(p=0.001)$. ALL patients with MTHFR C677T gene polymorphism were 4 times more likely to be resistant to MTX chemotherapy compared to patients who did not have the MTHFR C677T gene polymorphism ( $p=0.007)$. Therefore, this result supports our hypothesis that MTHFR C677T and TS 5'-UTR 3R/3R gene polymorphism correlates with MTX resistance in ALL patients.

\section{Discussion}

Leukemia patients who apparently fail to exhibit a therapeutic response (remission or complete remission) can be referred to as resistant to anti-leukemia drugs (clinical drug resistance).(5,15,16) In the pediatric population, ALL is the most common malignancy encountered in daily practice. One of the essential drugs used in ALL is MTX, which works as a folate antagonist to inhibit DNA synthesis, and resistance toward MTX does exist.

This phenomenon is often found in pediatric patients with ALL who have poor prognostic factors; for instance, maleshave worse prognosis than females and younger patients have a worse prognosis than older patients. $(17,18)$ However, in this study, it was not proven that age and gender were related to MTX resistance.In correlation with lymphoblast morphology, the results of this study

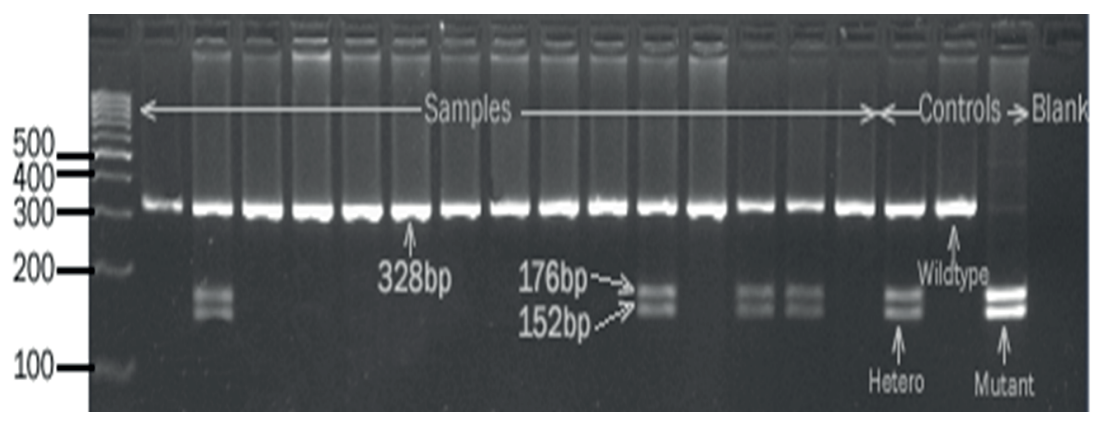

Figure 1. PCR-RFLP results of wildtype MTHFR CTH7 gene polymorphism produced 328 bp fragments. Heterozygotes produced 328 bp, 176 bp, and 152 bp fragments, whereas homozygous mutants produced 176 bp and 152 bp, positive control LS 174 T selline. This examination used a 100 bp DNA ladder marker. 


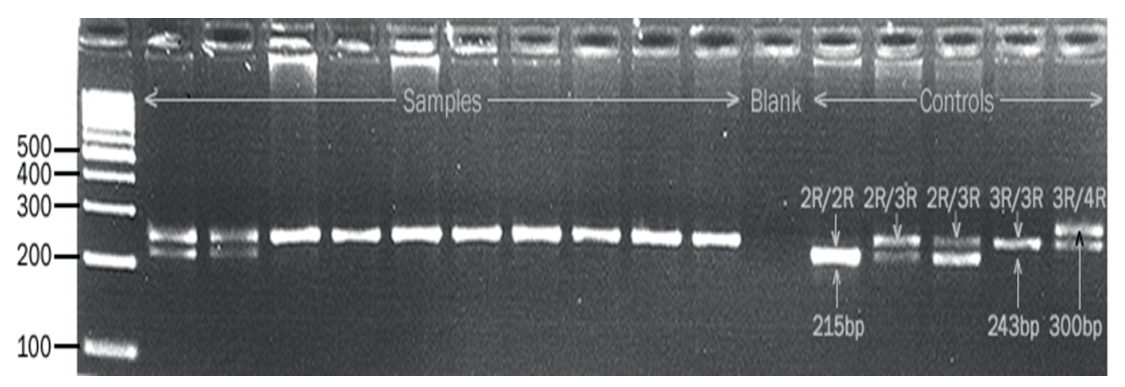

Figure 2. PCR results of TSER 5'-UTR $28 \mathrm{bp} 2 \mathrm{R} / 2 \mathrm{R}$ polymorphism produced $215 \mathrm{bp}$ fragments, $2 \mathrm{R} / 3 \mathrm{R}$ variants produced $215 \mathrm{bp}$ and $243 \mathrm{bp}$ fragments, 3R/3R produced $243 \mathrm{bp}$ fragments, whereas 3R/4R produced fragments of $215 \mathrm{bp}, 243 \mathrm{bp}$, and $300 \mathrm{bp}$. This examination used 100 bp DNA ladder marker.

were similar to those of previous studies that found no relationship between leukemia based on FAB classification and MTX resistance.(3)

Studies investigating MTX resistance in childhood ALL have mostly been carried out in laboratory base using cultured cells (8) and experimental animals. $(19,20)$ However, studies using cultured cells and experimental animals have been unable to solve the problem of MTX resistance. Thus, we conducted our study using human subjects.

MTHFR plays an important role in intracellular folate homeostasis through its involvement in two pathways of folate metabolism, which arein the synthesis of methionine and S-adenosyl methionine (SAM) and through thymidylate synthase needed for DNA synthesis. Polymorphisms in the gene that encodes MTHFR usually occur at the nucleotide 677 position where alanine is replaced by valine (C677T), and it has been proven that polymorphism in the MTHFR
C677T gene will cause enzyme activity to decrease significantly.(10,21-24) If there is a polymorphism in the MTHFR gene, the activity of the MTHFR enzyme will reduce, causing a decrease in the number of 5-MTHF due to an increase in the amount of homocysteine in the blood (hyperhomocysteinemia), which in turn will lead to increased toxicity or failure of chemotherapy. In addition to the decrease of 5-MTHF, decreased activity of the MTHFR enzyme also causes an increase in the amount of 5,10-MTHF, which provides a methyl group in the formation of thymidylate, a precursor needed for DNA synthesis. As a result, DNA synthesis continues and thus causes resistance. (14,25-32)

TS catalyzes dUMP to dTMP during process of DNA synthesis. TS enzyme polymorphism is a repeated sequence for every 28 base pairs (tandem repeat sequence) in the 5'UTR.(33) Polymorphism of the genes encoding the TS enzyme will increase gene expression in TS $(33,34)$,

Table1. Correlation between basic characteristics of samples and MTX resistance in childhood ALL.

\begin{tabular}{lccc}
\hline \multirow{2}{*}{ Characteristic } & \multicolumn{2}{c}{ Sample } & \\
\cline { 2 - 3 } & $\begin{array}{c}\text { Sensitive } \\
\mathbf{n}(\%)\end{array}$ & $\begin{array}{c}\text { Resistant } \\
\mathbf{n}(\%)\end{array}$ & \\
\hline Age & & & \\
$\quad<1$ year & & $1(100)$ & 0.721 \\
1 1-10 years & $48(34.8)$ & $90(65.2)$ & \\
$>10$ years & $4(25)$ & $12(75)$ & \\
\hline Gender & $32(36.8)$ & $55(63.2)$ & 0.428 \\
$\quad$ Male & $20(29.4)$ & $48(70.6)$ & \\
Female & & & \\
\hline Morphologic diagnosis & $50(34.7)$ & $94(65.3)$ & 0.357 \\
ALL type-L1 & $2(18.2)$ & $9(81.8)$ & \\
ALL type-L2 & &
\end{tabular}


Table 2. Cross-table of MTX resistance and gene polymorphism of MTHFR C677T in childhood ALL.

\begin{tabular}{lccc}
\hline \multirow{2}{*}{$\begin{array}{l}\text { Polymorphism } \\
\text { MTHFR C677T }\end{array}$} & $\begin{array}{c}c \\
\text { Sensitive } \\
\text { n (\%) }\end{array}$ & $\begin{array}{c}\text { Resistant } \\
\text { n (\%) }\end{array}$ & Total \\
\hline Negative & $46(39.3)$ & $71(60.7)$ & $117(75.5)$ \\
Positive & $6(15.8)$ & $32(84.2)$ & $38(24.5)$ \\
Total & $52(33.5)$ & $103(66.5)$ & $155(100)$ \\
\hline
\end{tabular}

Chi-square test $=6.105(p=0.013)$.

Table 3. Cross-table of MTX resistance and gene polymorphism of TS5'-UTR 3R/3R in childhood ALL.

\begin{tabular}{lccc}
\hline \multirow{2}{*}{$\begin{array}{c}\text { Polymorphism } \\
\text { TS 5'-UTR 3R/3R }\end{array}$} & \multicolumn{2}{c}{ Sample } & \multirow{2}{*}{ Total } \\
\cline { 2 - 3 } & $\begin{array}{c}\text { Sensitive } \\
\mathbf{n}(\%)\end{array}$ & $\begin{array}{c}\text { Resistant } \\
\mathbf{n}(\%)\end{array}$ & \\
\hline Negative & $13(68.4)$ & $6(31.6)$ & $19(12.3)$ \\
Positive & $39(28.7)$ & $97(71.3)$ & $136(87.7)$ \\
Total & $52(33.5)$ & $103(66.5)$ & $155(100)$ \\
\hline
\end{tabular}

Chi-square test $=10.097(p=0.001)$.

stimulating conversion ofdUMP to dTMP, increasing DNA synthesis, and ultimately leading to MTX resistance. $(12,30,35)$

Furthermore, this study also found that $31.6 \%$ of ALL patients resistant to MTX did not display TS5'UTR 3R/3R polymorphism. This resistance to MTX can be caused by other gene polymorphisms, such as reduced folate carrier (RFC) transport, dihydrofolate reductase (DHFR), folypolyglutamate hydrolase (FPGH), and folypolyglutamatesynthetase (FPGS).(36) Combinations of several polymorphisms of hydrolase genes involved in folate metabolism should also be investigated in further studies.

\section{Conclusion}

It is concluded that ALL patients with TS 5'-UTR 3R/3R polymorphism had 4 times greater probability of being MTX resistant than without TS 5'-UTR 3R/3R polymorphism, and also patients with MTHFR C677T gene polymorphism were 4 times more likely to be resistant to MTX. The most dominant gene causing MTX resistance is TS 5'-UTR $3 R / 3 R$.

\section{References}

1. Pui $\mathrm{CH}$, Mullighan CG, Evans WE, Relling MV. Pediatric acute lymphoblastic leukemia: where are we going and how do we get there? Blood. 2012; 120: 1165-74.

2. Pui CH, Campana D. New definition of remission in childhood acute lymphoblastic leukemia. Leukemia. 2000; 14: 783-5.

3. Carroll WL, Bhojwani D, Min DJ, Raetz E, Relling M, Davies S, et al. Pediatric acute lymphoblastic leukemia. Hematology. 2003; 2003: 102-31.

4. Poplack DG. Acute lymphoblastic leukemia. In: Pizzo PA, Poplack DG, editors. Principles and Practice of Pediatric Oncology. 5th edition. Philadelphia: Lippincott Williams \& Wilkins; 2006. p.323-66.

5. Radtke S, Zolk O, Renner B, Paulides M, Zimmermann M, Möricke A, et al. Germline genetic variations in methotrexate candidate genes are associated with pharmacokinetics, toxicity, and outcome in childhood acute lymphoblastic leukemia. Blood. 2013; 121: 514553.

6. de Beaumais TA, Jacqz-Aigrain E. Intracellular disposition of methotrexate in acute lymphoblastic leukemia in children. Curr Drug Metab. 2012; 13: 822-34.

7. Chiusolo P, Reddiconto G, Cimino G, Sica S, Fiorini A, Farina G, et al. Methylenetetrahydrofolate reductase genotypes do not play a role in acute lymphoblastic leukemia pathogenesis in the Italian population. Haematologica. 2004; 89: 139-44.

8. Kaufman Y, Drori S, Cole PD, Kamen BA, Sirota J, Ifergan I, et al. Reduced folate carrier mutations are not the mechanism underlying methotrexate resistance in childhood acute lymphoblastic leukemia. Cancer. 2004; 100: 773-82. 
9. Schnakenberg E, Mehles A, Cario G, Rehe K, Seidemann K, Schlegelberger B, et al. Polymorphisms of methylenetetrahydrofolate reductase (MTHFR) and susceptibility to pediatric acute lymphoblastic leukemia in a German study population. BMC Med Genet. 2005; 6: 23. doi: 10.1186/1471-2350-6-23.

10. Umerez M, Gutierrez-Camino Á, Muñoz-Maldonado C, MartinGuerrero I, Garcia-Orad A. MTHFR polymorphisms in childhood acute lymphoblastic leukemia: influence on methotrexate therapy. Pharmgenomics Pers Med. 2017; 10: 69-78.

11. Chatzidakis K, Goulas A, Athanassiadou-Piperopoulou F, Fidani L, Koliouskas D, Mirtsou V. Methylenetetrahydrofolate reductase C677T polymorphism: Association with risk for childhood acute lymphoblastic leukemia and response during the initial phase of chemotherapy in greek patients. Pediatr Blood Cancer. 2006; 47: 147-51.

12. Ugrasena I, Sutaryo S, Supriadi E, Vroling L, Cloos J, Hooijberg $\mathrm{JH}$, et al. High frequency of the $3 \mathrm{R} / 3 \mathrm{R}$ polymorphism in the thymidylate synthase enhancer region in Indonesian childhood acute lymphoblastic leukemia. Paediatr Indones. 2016; 46: 103-12.

13. Giovannetti E, Ugrasena DG, Supriyadi E, Vroling L, Azzarello A, de Lange D, et al. Methylenetetrahydrofolate reductase (MTHFR) C677T and thymidylate synthase promoter (TSER) polymorphisms in Indonesian children with and without leukemia. Leuk Res. 2008; 32: 19-24.

14. Unit Koordinasi Kerja (UKK) Hematologi-Onkologi Ikatan Dokter Anak Indonesia. Panduan Protokol Nasional Leukemia Limfoblastik Akut 2013. [Unpublished Material].

15. Gervasini G, Vagace JM. Impact of genetic polymorphisms on chemotherapy toxicity in childhood acute lymphoblastic leukemia. Front Genet. 2012; 3: 249. doi: 10.3389/fgene.2012.00249.

16. Holleman A, Cheok MH, den Boer ML, Yang W, Veerman AJP, Kazemier KM, et al. Gene-expression patterns in drug-resistant acute lymphoblastic leukemia cells and response to treatment. $\mathrm{N}$ Engl J Med. 2004; 351: 533-42.

17. Chessells JM, Richards SM, Bailey CC, Lilleyman JS, Eden OB. Gender and treatment outcome in childhood lymphoblastic leukaemia: report from the MRC UKALL trials*. Br J Haematol. 1995; 89: 364-72.

18. Kanerva J. Prognostic Factors in Childhood Acute Lymphoblastic Leukemia (ALL). Helsinki: University of Helsinki; 2001.

19. Gorlick R, Goker E, Trippett T, Waltham M, Banerjee D, Bertino JR. Intrinsic and acquired resistance to methotrexate in acute leukemia. N Engl J Med. 1996; 335: 1041-8.

20. Zhao R, Assaraf YG, Goldman ID. A reduced folate carrier mutation produces substrate-dependent alterations in carrier mobility in murine leukemia cells and methotrexate resistance with conservation of growth in 5-formyltetrahydrofolate. J Biol Chem. 1998; 273: 7873-9.

21. Frosst P, Blom HJ, Milos R, Goyette P, Sheppard CA, Matthews RG, et al. A candidate genetic risk factor for vascular disease: a common mutation in methylenetetrahydrofolate reductase. Nat Genet. 1995; 10: 111-3.

22. Weisberg I, Tran P, Christensen B, Sibani S, Rozen R. A second genetic polymorphism in methylenetetrahydrofolate reductase (MTHFR) associated with decreased enzyme activity. Mol Genet Metab. 1998; 64: 169-72.
23. van der Put NM, Gabreëls F, Stevens EM, Smeitink JA, Trijbels FJ, Eskes TK, et al. A second common mutation in the methylenetetrahydrofolate reductase gene: an additional risk factor for neural-tube defects? Am J Hum Genet. 1998; 62: 1044-51.

24. Ueland PM, Hustad S, Schneede J, Refsum H, Vollset SE. Biological and clinical implications of the MTHFR C677T polymorphism. Trends Pharmacol Sci. 2001; 22: 195-201.

25. Toffoli G, Russo A, Innocenti F, Corona G, Tumolo S, Sartor F, et al. Effect of methylenetetrahydrofolate reductase $677 \mathrm{C}-->\mathrm{T}$ polymorphism on toxicity and homocysteine plasma level after chronic methotrexate treatment of ovarian cancer patients. Int $\mathrm{J}$ cancer. 2003; 103: 294-9.

26. Ulrich CM, Yasui Y, Storb R, Schubert MM, Wagner JL, Bigler J, et al. Pharmacogenetics of methotrexate: toxicity among marrow transplantation patients varies with the methylenetetrahydrofolate reductase C677T polymorphism. Blood. 2001; 98: 231-4.

27. Taub JW, Matherly LH, Ravindranath Y, Kaspers GJL, Rots MG, Zantwijk CH. Polymorphisms in methylenetetrahydrofolate reductase and methotrexate sensitivity in childhood acute lymphoblastic leukemia. Leukemia. 2002; 16: 764-5.

28. Chiusolo P, Reddiconto G, Casorelli I, Laurenti L, Sorà F, Mele L, et al. Preponderance of methylenetetrahydrofolate reductase C677T homozygosity among leukemia patients intolerant to methotrexate. Ann Oncol Off J Eur Soc Med Oncol. 2002; 13: 1915-8.

29. Ulrich CM, Robien K, McLeod HL. Cancer pharmacogenetics: polymorphisms, pathways and beyond. Nat Rev Cancer. 2003; 3 : 912-20.

30. Wiemels JL, Smith RN, Taylor GM, Eden OB, Alexander FE, Greaves MF, et al. Methylenetetrahydrofolate reductase (MTHFR) polymorphisms and risk of molecularly defined subtypes of childhood acute leukemia. Proc Natl Acad Sci USA. 2001; 98: 4004-9.

31. Aplenc R, Thompson J, Han P, La M, Zhao H, Lange B, et al. Methylenetetrahydrofolate reductase polymorphisms and therapy response in pediatric acute lymphoblastic leukemia. Cancer Res. 2005; 65: 2482-7.

32. Krajinovic M, Lemieux-Blanchard E, Chiasson S, Primeau M, Costea I, Moghrabi A. Role of polymorphisms in MTHFR and MTHFD1 genes in the outcome of childhood acute lymphoblastic leukemia. Pharmacogenomics J. 2004; 4: 66-72.

33. Cole PD, Drachtman RA, Smith AK, Cate S, Larson RA, Hawkins DS, et al. Phase II trial of oral aminopterin for adults and children with refractory acute leukemia. Clin Cancer Res. 2005; 11: 8089-96.

34. Kawakami K, Omura K, Kanehira E, Watanabe Y. Polymorphic tandem repeats in the thymidylate synthase gene is associated with its protein expression in human gastrointestinal cancers. Anticancer Res. 1999; 19: 3249-52.

35. Krajinovic M, Costea I, Chiasson S. Polymorphism of the thymidylate synthase gene and outcome of acute lymphoblastic leukaemia. Lancet. 2002; 359: 1033-4.

36. Wojtuszkiewicz A, Peters GJ, van Woerden NL, Dubbelman B, Escherich G, Schmiegelow K, et al. Methotrexate resistance in relation to treatment outcome in childhood acute lymphoblastic leukemia. J Hematol Oncol. 2015; 8: 61. doi: 10.1186/s13045-0150158-9. 